\title{
The effects of phosphorus supplementation on body mass and reproduction of grazing beef cows supplemented with different levels of phosphorus at Armoedsvlakte
}

\author{
H.O. de Waal', J.H. Randall ${ }^{2}$ and G.J. Koekemoer ${ }^{3}$ \\ Glen Agricultural Development Institute, Department of Agriculture, Free State Province, \\ Private Bag X01, Glen, 9360 Republic of South Africa
}

Received 9 November 1995; accepted 6 February 1996

\begin{abstract}
In an attempt to quantify the requirement for supplementary phosphorus $(P)$ of grazing beef cattle at Armoedsvlakte (which is notorious for its $P$ deficient pastures), 66 cows received supplementary $P$ per fistulam from 1984 to 1989. Supplementation was provided according to a $3 \times 2$ factorial of three levels of $P$ (Low, Medium and High), in periods of either all year round (LP 12, MP 12 and HP 12) or six months only (LP 6, MP 6 and HP 6), i.e. September to February. The body mass of cows, averaged over the 59 months of the experiment, displayed no Period $\times$ Level interaction and, of the two main effects, only Period was significant 0.0162 ). Cows re-ceiving $P$ all year round averaged $33 \pm 13.0 \mathrm{~kg}$ heavier than those receiving $P$ for only six months of the year. Regarding reproductive performance, the birth mass of calves varied significantly from year to year, but there was no year by treatment interaction, indicating that the treatment effects were consistent over years. Amongst treatment factors, birth mass varied only according to Level of $P$ supplementation $(P=0.0463)$. Weaning percentage varied almost significantly according to Period of $P$ supplementation $(P=0.0563)$ and displayed an almost significant linear response to Level of $\mathrm{P}$ supplementation $(P=0.0560)$. The joint significance level for this model was $P=0.0261$. The weaning mass of calves and their average daily growth (ADG) showed significant differences only according to year of birth. The significant effect of treatment (level of $P$ supplementation) on calf birth mass but not on weaning mass suggests that if there is a P deficiency, cows will draw on their reserves to shield the calf from such a deficiency. A financial analysis suggests that the greatest financial advantage would be accrued by supplementing reproducing beef cows according to the HP 12 treatment, i.e. $16 \mathrm{~g} \mathrm{P}$ day during late gestation to late lactation (September to February) and $9 \mathrm{~g} \mathrm{P}$ day ${ }^{-1}$ during the remainder of the year.
\end{abstract}

In 'n poging om die behoefte aan aanvullende fosfor $(P)$ van vleisbeeste wat by Armoedsvlakte wei (wat bekend is vir die P-gebrekkige weidings) te bepaal, het 66 koeie aanvullende $P$ vanaf 1984 tot 1989 per fistulam ontvang. Aanvulling is voorsien volgens ' $n 3 \times 2$ faktoriaal van drie Vlakke van $P$ (Laag, Medium en Hoog) in Periodes van óf die hele jaar (LP 12, MP 12 en HP 12) óf vir slegs ses maande (LP 6, MP 6 en HP 6), naamlik September tot Februarie. Die liggaamsmassa van koeie, gemeet as die gemiddelde maandelikse massa van elk van die 59 maande van die eksperiment, het geen Periode $\times$ Vlak wisselwerking getoon nie, en onder die twee hoofeffekte, was slegs Periode betekenisvol $(P=0.0162)$. Koeie wat dwarsdeur die jaar $P$ ontvang het, was 33 $\pm 13.0 \mathrm{~kg}$ swaarder as koeie wat $P$ slegs gedurende ses maande van die jaar ontvang het. Met betrekking tot reproduktiewe prestasie, het die massa van kalwers by geboorte van jaar tot jaar betekenisvol verskil, maar geen jaar met behandeling wisselwerking is waargeneem nie, wat daarop dui dat behandelingseffekte oor jare konsekwent was. Onder die behandelingsfaktore het die geboortemassa slegs volgens Vlak van aanvullende $P$ verskil $(P=0.0463)$. Speenpersentasie het amper betekenisvol volgens Periode verskil $(P=0.0563)$ en het 'n amper betekenisvolle lineêre respons volgens Vlak van aanvullende $P$ vertoon $(P=0.0560)$. Die gesamentlike betekenisvolheid van hierdie twee faktore was $P=0.0261$. Die speenmassa van kalwers en hul gemiddelde daaglikse toename (GDT) het slegs volgens jaar van geboorte betekenisvol verskil. Die betekenisvolle effek van behandeling (vlak van aanvullende $P$ ) op geboortemassa maar nie op speenmassa van kalwers, dui daarop dat koeie in die geval van ' $n$ gebrek aan $P$ van liggaamsreserwes gebruik sal maak om hul kalwers teen sulke tekorte te beskerm. ' $n$ Finansiële ontleding dui daarop dat die grootste finansiële voordeel getrek word as P-aanvulling aan reproduserende vleisbeeskoeie volgens die HP 12 behandeling geskied, $\mathrm{nl}$. $16 \mathrm{~g} \mathrm{P} \mathrm{dag}{ }^{-1}$ gedurende laat dragtigheid tot laat laktasie (September tot Februarie) en $9 \mathrm{~g} \mathrm{P} \mathrm{dag}^{-1}$ gedurende die res van die jaar.

Keywords: Grazing cattle, native pasture, phosphorus deficiency, rumen fistula, salt $(\mathrm{NaCl})$, veld

' To whom correspondence should be addressed

${ }^{2}$ Biometrician, Faculty of Agricultural Sciences, University of Stellenbosch, Private Bag X1, Matieland, 7602 Republic of South Africa

${ }^{3}$ Armoedsvlakte Research Station, P.O. Box 14, Vryburg, 8600 Republic of South Africa

\section{Introduction}

The pioneering work of Sir Arnold Theiler at the turn of the century (Theiler, 1912), and more recent work of Read et al. (1986a,b,c), have identified phosphorus (P) as a major limiting nutrient for beef cattle at Armoedsvlakte, in the Northern Cape (now part of the North West Province). However, the supplementary $P$ requirements of grazing beef cattle are not known with certainty. Consequently, recommendations for $P$ supplementation are based largely on speculation. From an economic point of view it is imperative to quantify the sup- plementary $\mathrm{P}$ requirements of cattle. Many producers may oversupply cattle with supplementary $P$, while others undersupply. Both scenarios may have an impact on animal production and financial returns (Read et al., 1986a).

Speculation over the $P$ requirements of grazing cattle exists, because of the difficulty of determining the $P$ intake of grazing ruminants, as well as the dependence of $P$ requirements on the levels of protein and digestible energy of the pasture available for grazing animals. Sampling of pastures with oesophageally fistulated animals offers the most reliable approach to determine the protein and digestible organic mat- 
ter contents of the diet selected by an animal, but because of salivary contamination of the samples, this method is not appropriate for a mineral like $\mathrm{P}$, unless salivary $\mathrm{P}$ is labelled with ${ }^{32} \mathrm{P}$ (Little et al., 1977). Additionally, if an animal grazes until satiated (or until the grazing is exhausted), the actual amount of $P$ ingested will be confounded with the amount of protein and digestible energy consumed. This makes it impossible to relate $P$ consumption to an animal's production. Considering that the intake of digestible organic matter and crude protein of P-supplemented cattle grazing at Armoedsvlakte were adequate (Read et al., 1986a), this site should be suited ideally for an experiment to test supplementary $P$ requirements.

The cost of $P$ supplementation must be justified by an increase in animal production or in the value of the animals. In a previous trial at Armoedsvlakte (Read et al., 1986a), cows receiving $P$ supplementation yielded a financial benefit from their second calving season onwards. However, despite the success of this earlier study, quantitative supplementary $P$ requirements of grazing beef cattle remain unknown. The purpose of this study was, therefore, to quantify the supplementary $P$ requirement of grazing beef cows at Armoedsvlakte. This paper will deal with the effects of $P$ supplementation on body mass and reproductive performance. The value of blood, rib bone and rumen fluid as indicators of the $P$ status of cattle is discussed in a second paper (De Waal \& Koekemoer, 1996).

\section{Experimental procedure}

This trial was conducted at the Armoedsvlakte Research Station, which is situated in the Northern Cape, about $10 \mathrm{~km}$ west of Vryburg, at an altitude of $1235 \mathrm{~m}$ above sea level. Acocks (1988) classified the veld type as Kalahari Thornveld (no. 16 b1) (with the subdivision Vryburg Shrub Bushveld and a further subdivision Tarchonanthus veld of the Ghaap plateau), comprising the dominant grasses Themeda triandra and Digitaria seriata and bush species Tarchonanthus camphoratus and Grewia flava. The underlying rock is chalk and dolomite, with a shallow top soil $(250-500 \mathrm{~mm})$ of the Mispah soil series. The long-term annual rainfall (1959-1993) of Armoedsvlakte is $485.6 \mathrm{~mm}$.

In July and August 1984, four to five months before their first breeding season, 66 Bonsmara-type crossbred heifers were fitted with large rumen cannulae $(80 \mathrm{~mm}$ inner diameter), according to the method described by Read (1984). Before the start of the trial in September 1984, the heifers had free access to a salt/dicalcium phosphate lick. The heifers were allotted randomly to six treatments (11 animals each) and were managed as a single grazing herd, since supplementary $\mathbf{P}$ was placed directly into the rumen. The six treatments were arranged as a factorial combination of 2 Periods and 3 Levels of P supplementation per fistulam, as detailed in Table 1. Supplementation of P via rumen fistulae began in September 1984 , with dicalcium phosphate (minimum $16 \% \mathrm{P}$ ) as the source of $P$.

According to the ARC (1980) recommendations, the $\mathrm{P}$ requirements of a $450 \mathrm{~kg}$ beef cow during the last two months of gestation are $16 \mathrm{~g} \mathrm{P}$ day $^{-1}$, and $9 \mathrm{~g} \mathrm{P}$ day $^{-1}$ for maintenance. These recommended levels, which were used to define the treatment HP 12 in the current trial, may be slightly more than
Table 1 The treatment design, with the different levels and periods of phosphorus $(P)$ supplementation per fistulam to the breeding beef cows in the six treatments

\begin{tabular}{|c|c|c|}
\hline \multirow[b]{3}{*}{ Treatment labels ${ }^{1}$} & \multicolumn{2}{|c|}{ Method and interval of supplementation } \\
\hline & $\begin{array}{l}\text { March to August } \\
\text { Weekly allowance }{ }^{2} \text {, was } \\
\text { given in } 2 \text { doses (Monday } \\
\& \text { Friday) }\end{array}$ & $\begin{array}{l}\text { September to February } \\
\text { Weekly allowance }{ }^{3} \text {, was } \\
\text { given in } 3 \text { doses (Monday, } \\
\text { Wednesday \& Friday) }\end{array}$ \\
\hline & \multicolumn{2}{|c|}{ Level of supplementation ( $\left.\mathrm{g} \mathrm{P} \mathrm{day}{ }^{-1}\right)$} \\
\hline LP 6 & - & 5 \\
\hline MP 6 & - & 10 \\
\hline HP 6 & - & 16 \\
\hline LP 12 & 3 & 5 \\
\hline MP 12 & 6 & 10 \\
\hline HP 12 & 9 & 16 \\
\hline
\end{tabular}

${ }^{1}$ LP 6, MP 6, HP 6: Low, medium and high levels of $P$ for 6 months/year.

LP 12, MP 12, HP 12: Low, medium and high levels of P for 12 months/ year.

${ }^{2}$ LP 6, MP 6, HP 6: None.

LP 12, MP 12, HP 12: Provided as 65, 130 or $197 \mathrm{~g}$ dicalcium phosphate, 2 times per week.

${ }^{3}$ Provided as 73,146 or $233 \mathrm{~g}$ dicalcium phosphate, 3 times per week.

absolute requirements (Little, 1980). For example, Read et al. (1986a), in a trial at Glen Agricultural Development Institute, dosed cows by way of rumen fistulae at 12 and $8 \mathrm{~g} \mathrm{P}_{\text {day }}{ }^{-1}$, respectively, in the same two periods concerned. Although these authors did not provide details of the lick consumed by cows in a trial at Armoedsvlakte, Table 8 in Read et al. (1986a) suggests that cows consumed on average about $9.5 \mathrm{~g}$ $\mathrm{P}$ day $^{-1}$ (over five years), which is comparable to the MP 12 treatment in this study (Table 1).

The animals were managed as one grazing and breeding herd at a stocking rate of 7 ha/Large Stock Unit (LSU; Meissner et al., 1983) and were rotated through 10 camps in an open grazing system. Besides the supplementary $\mathrm{P}$ per fistulam (Table 1), the animals were given free access to a coarse salt lick. Lick consumption was monitored monthly on a group basis. As proposed by De Waal (1990), the mating season during the first year of the trial (when the animals were heifers) lasted from 20 November 1984 to 28 February 1985 , and from 15 December to 28 February in the remaining years. All breeding females were mated in one group with three bulls. The trial lasted until weaning of the fourth set of calves in June 1989. However, since 54 of the remaining 59 rumen fistulated cows were diagnosed as being pregnant in May 1989 , it was decided not to mate them again in December 1989 , but to keep them open until weaning of their fifth set of calves in June 1990. Calves were weighed within $24 \mathrm{~h}$ of birth and weaned at 205 days of age. All animals were weighed towards the end of each month. Feed and water were not withheld from the cows and calves before being weighed in the morning.

Two pregnant heifers died (LP 6 - September and MP 6 August) before giving birth to their first calves in 1985 and three more died (LP 6 - October, MP 6 - September and HP 12 - October) while giving birth to their first calves or soon thereafter. These deaths were associated directly with the 
poor condition of some animals as a result of a severe drought during 1984/85; all data on these animals are excluded. Data on the other cow fatalities which occurred later during the trial (MP 12 - June 1988, LP 12 - July 1989, HP 6 - November 1989 and MP 6 - December 1989) are also excluded.

Most analyses were done using the General Linear Model procedure (PROC GLM) of the Statistical Analysis System (SAS, 1989), the exceptions arising in the case of binary data, where PROC LOGISTIC was used. In these cases, the error was assumed to be binomial and a logit link function was used.

\section{Results and Discussion}

In the trial of Read et al. (1986a) conducted at Glen, rumen cannulae were inserted when the heifers were about 17 to 18 months old (March). Initially, this may have put the animals at a disadvantage, but they recovered. In the present trial, the heifers were four to five months older at the time of rumen cannulation (July/August) and no apparent disadvantage was detected. Furthermore, considering the ability of heifers to ovulate and conceive during their first mating season as measure of their well-being, 64 of the 66 heifers (or 97\%) conceived within four to five months of rumen fistulation. In the trial at Glen (Read et al., 1986a), 15 of the 16 rumen fistulated heifers (or 94\%) also conceived during their first mating season. This suggests that the rumen fistulation technique did not impair the normal functions of rumen-fistulated heifers and cows as reproducing experimental animals.

\section{Body mass of cows}

The monthly body mass of each of the surviving cows (of the original 66 heifers) was measured over the entire period of the experiment, a total of 59 months. Averaging the 59 measurements for each of the 57 surviving cows, the analysis of variance (ANOVA) of this variable is given as a footnote in Table 2. The ANOVA table shows that there was no interaction between Period and Level, that the Level main effect was not significant, but that the significance level for Period was 0.0162 .

Thus, cows receiving a $\mathrm{P}$ supplement for only six months of the year had an average body mass during the 59 months of the study of $472 \pm 9.39 \mathrm{~kg}$, compared to the average of $505 \pm$ $9.05 \mathrm{~kg}$ observed for the cows which were supplemented all year round, a difference of $33 \pm 13.0 \mathrm{~kg}$. This suggested that supplementation during only the 'reproduction' period (September to February, i.e. from just before calving, through early to mid-lactation and during mating) was insufficient for the general well-being of cows.

In a second reduction, cow live weights were averaged according to month to investigate seasonal trends in live weight change. In the analysis of these 12 new variables (called 'January', through to 'December'), only the Period main effect was found significant, or nearly so. Thus, averaging the measurements taken in September of each of the five years (1985 to 1989) of the study, the factor Period was highly significant $(P=0.0032)$; for December the significance level for Period was 0.0308 , while in March it was 0.0882 and in June it was 0.0082 . The results of these analyses are summarised in Table 2 and also graphically displayed in Figure 1.
Table 2 Monthly body mass of cows ${ }^{3}$, averaged over five years

\begin{tabular}{|c|c|c|c|}
\hline \multirow[b]{3}{*}{ Month } & \multicolumn{2}{|c|}{ Period (Months) } & \multirow{3}{*}{$\begin{array}{c}\text { Difference } \\
\mathbf{k g} \pm \mathrm{se}\end{array}$} \\
\hline & $6^{2}$ & 12 & \\
\hline & $\mathrm{kg} \pm \mathrm{se}$ & $\mathrm{kg} \pm \mathrm{se}$ & \\
\hline September & $435 \pm 9.05$ & $474 \pm 8.72$ & $39 \pm 12.6$ \\
\hline October & $432 \pm 8.05$ & $468 \pm 7.76$ & $36 \pm 11.2$ \\
\hline November & $439 \pm 8.38$ & $471 \pm 8.08$ & $32 \pm 11.6$ \\
\hline December & $464 \pm 8.58$ & $491 \pm 8.27$ & $27 \pm 11.9$ \\
\hline January & $476 \pm 9.14$ & $498 \pm 8.81$ & $22 \pm 12.7$ \\
\hline February & $483 \pm 9.40$ & $506 \pm 9.06$ & $23 \pm 13.1$ \\
\hline March & $503 \pm 9.92$ & $527 \pm 9.56$ & $24 \pm 13.8$ \\
\hline April & $508 \pm 10.43$ & $538 \pm 10.05$ & $30 \pm 14.5$ \\
\hline May & $504 \pm 10.53$ & $534 \pm 10.15$ & $30 \pm 14.6$ \\
\hline June & $482 \pm 10.57$ & $523 \pm 10.19$ & $41 \pm 14.7$ \\
\hline July & $479 \pm 10.58$ & $519 \pm 10.20$ & $40 \pm 14.7$ \\
\hline August $^{1}$ & $461 \pm 10.01$ & $517 \pm 9.65$ & $56 \pm 13.9$ \\
\hline
\end{tabular}

${ }^{1}$ Averaged over four years, all other months averaged over five years.

${ }^{2}$ The cows in the group labelled "6-months" received no supplementation from March to August.

${ }^{3}$ ANOVA (Analysis of variance) table for body mass of cows, averaged over the monthly measurements of all 59 months of the trial

\begin{tabular}{lccc}
\hline Source of variation & $d f^{4}$ & Mean square & Significance level \\
\hline Period of supplementation $(=\mathrm{P})$ & 1 & 15627.96 & 0.0162 \\
Level of phosphorus $(=\mathrm{L})$ & 2 & 3048.70 & 0.3082 \\
$\mathrm{P} \times \mathrm{L}$ & 2 & 1385.41 & 0.5820 \\
Error & 54 & 2534.09 & \\
\hline
\end{tabular}

${ }^{4} d f=$ Degrees of freedom.

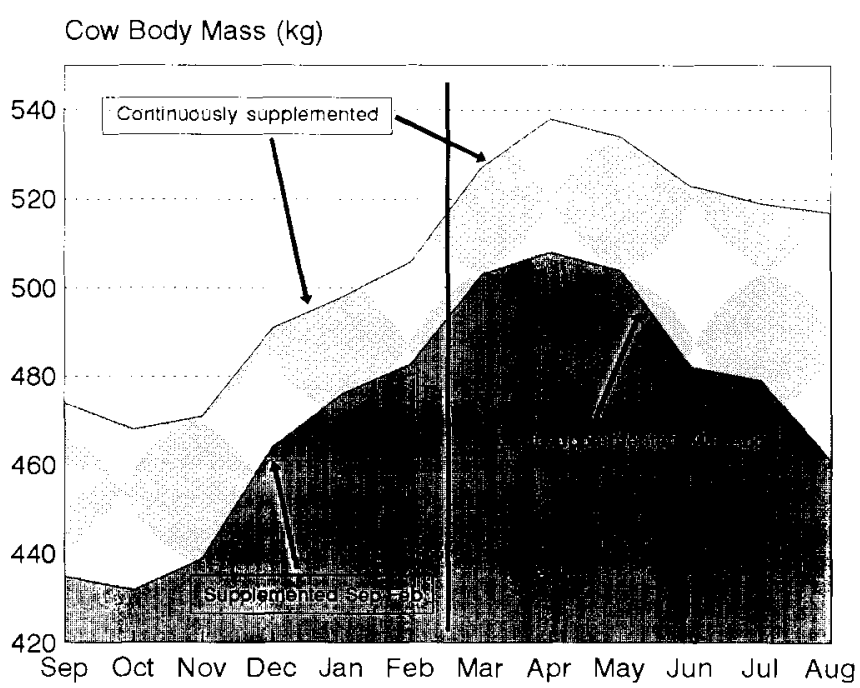

Figure 1 Average monthly body mass of cows supplemented continuously or only during six months of the year.

Since one is averaging the mass of the same animal at five ages, it is difficult to interpret the monthly means shown in Table 2. However, the differences in the last column of Table 2 , the difference between the two Period groups, are interpretable. In the six months in which both groups received supplementation (from September to February), there was a steady 
decline in the difference between the groups. In the following six months (in which the '6-month' group received no supplementation) the difference between groups steadily increased. A simple means of establishing the significance of this apparent pattern is to calculate

\section{(June + September - December - March)}

2

for each animal and analyse this variable. The months chosen correspond to a 'middle' month in the two six-month periods and a lagged month at the end of a period (in fact the first month of the new period, taken as a response to the supplementation in the previous six months). The thick lines drawn in Table 2 and Figure 1 indicate the division of the year into two six-month periods. As before, only the Period main effect is significant in this analysis, leading to a difference of [ $(41+$ $39-27-24) / 2=] 14.5 \pm 2.73 \mathrm{~kg}$. As shown clearly in Figure 1 , the animals did not make up for the lack of P supplement in one half of the year during the other half of the year, when they received the same $P$ supplements.

Read et al. (1986a) also reported considerable differences in body mass of the $+\mathrm{P}$ and $-\mathrm{P}$ cows at Armoedsvlakte. From the second year onwards, the body mass of the $-\mathrm{P}$ cows was, on average, $121 \mathrm{~kg}$ less, although both groups followed the same pattern in body mass changes, as a result of being exposed to the same set of environmental conditions. Survival was also markedly improved by supplementation, as shown by the cumulative mortality rate of $58.3 \%$ for the $-\mathrm{P}$ cows, compared to $27.3 \%$ for the $+\mathrm{P}$ cows (Read et al., 1986a). In the present trial, five pregnant heifers died between August and October 1985 as a direct result of the harsh conditions prevailing during a severe drought. By the end of the fourth breeding cycle (weaning, 1989), 60 of the original 66 animals (or $91 \%$ ) were still in the trial. Even the highest mortality rate in the present trial, i.e. $18 \%$ recorded over four breeding cycles in the LP 6 and MP 6 groups, was much lower than that reported by Read et al. (1986a) for the +P cows. However, since these two trials were conducted in different climatological periods, no plausible explanations can be suggested.

The average body mass of heifers and cows in the respective treatments, averaged over five years for each at four 3month-intervals (September, December, March and June), is presented in Figure 2.

By averaging data over years, the average body mass of a 'herd' consisting of heifers and cows in their Ist to 4 th breeding cycles is mimicked. This shows that the body mass of cows changes through the year as a result of successive physiological stages (gestation and lactation) and the seasonal changes in nutritive value of the veld (De Waal, 1990). The highest average cow mass (according to the presentation in Figure 2) is reached during March, i.e. after the mating season and towards the end of lactation, which also coincides with the period during which the veld reaches a peak in nutritive value. De Waal (1990) showed that the highest cow mass at Armoedsvlakte was in fact reached from May to June. An increase in average cow mass with increasing age (during corresponding months) was also evident in the data, but not shown here. Similar tendencies of an increase in birth and weaning mass of calves with age of dams, have also been observed.

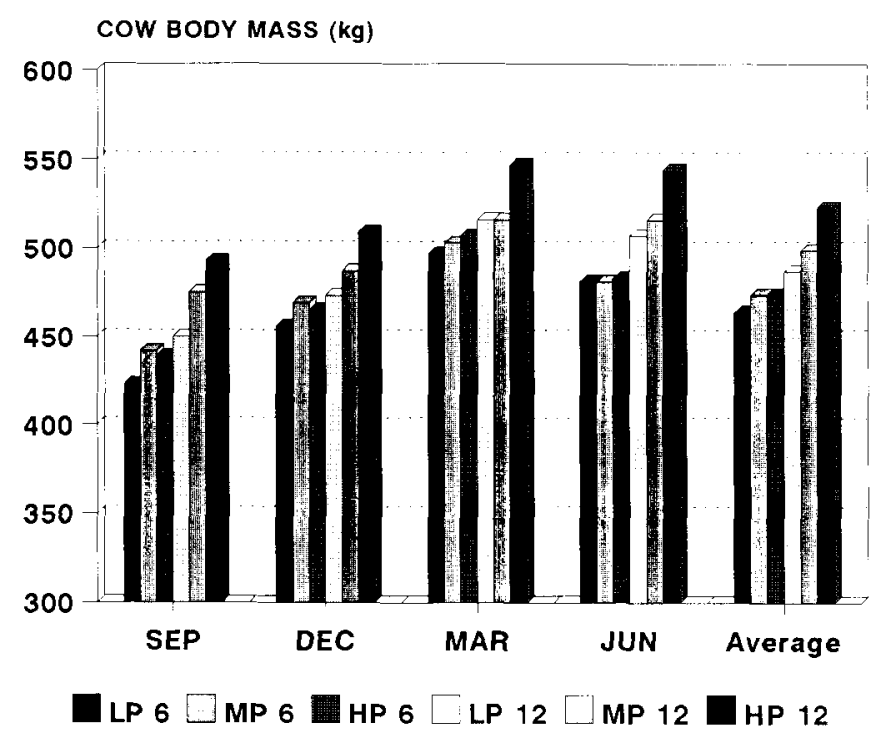

Figure 2 Average body mass of heifers and cows in the respective treatments, averaged over five years for each at four 3-monthly intervals (September, December, March and June).

\section{Reproductive performance}

The ability of the cows in each of the six treatments to produce a calf, dead or alive (calving percentage), as well as their ability to rear the calves to weaning (weaning percentage), are important measurements of response to the different treatments (See Annexure A for the actual data set). Although it may be an over-simplification, the LP 6 group exhibited a general calving percentage pattern of calf - skip - calf - skip, whereas the LP 12 group generally calved for two successive years and then skipped a season. The calving percentages of these two groups over five years were very similar, but favoured the LP 12 group. Taking the weaning of a calf (or not) by a cow during one of the five years of the study as a success (or failure) in one of five trials, the resulting analysis of deviance is shown in Table 3.

It should be noted that the two degrees of freedom $(d f)$ for Level were partitioned as though for three equally spaced levels. This is a simplification of that which was actually done in the trial. The levels were 73, 146 and 233 in six months of the year and 65, 130 and 197 in the other six months (Table 1). The levels would have been equal if the third levels had been 219 and 195, respectively, or the second-level values had been 153 and 131, respectively. Keeping this simplification in mind, the analysis of deviance shows that individually, the

Table 3 Analysis of deviance for the weaning percentages of a herd of cows

\begin{tabular}{ccccc}
\hline Source of variation & $d f$ & Deviance & Significance level \\
\hline Treatments & 5 & \multicolumn{2}{c}{7.633} & 0.1777 \\
Period = P & 1 & 3.644 & 0.0563 \\
Level = L & 2 & 3.749 & 0.1534 \\
Linear & & 1 & 3.651 & 0.0560 \\
Quadratic & & 1 & 0.098 & 0.7538 \\
P $\times$ L & 2 & & 0.239 & 0.8872 \\
\hline
\end{tabular}

I $d f=$ Degrees of freedom. 


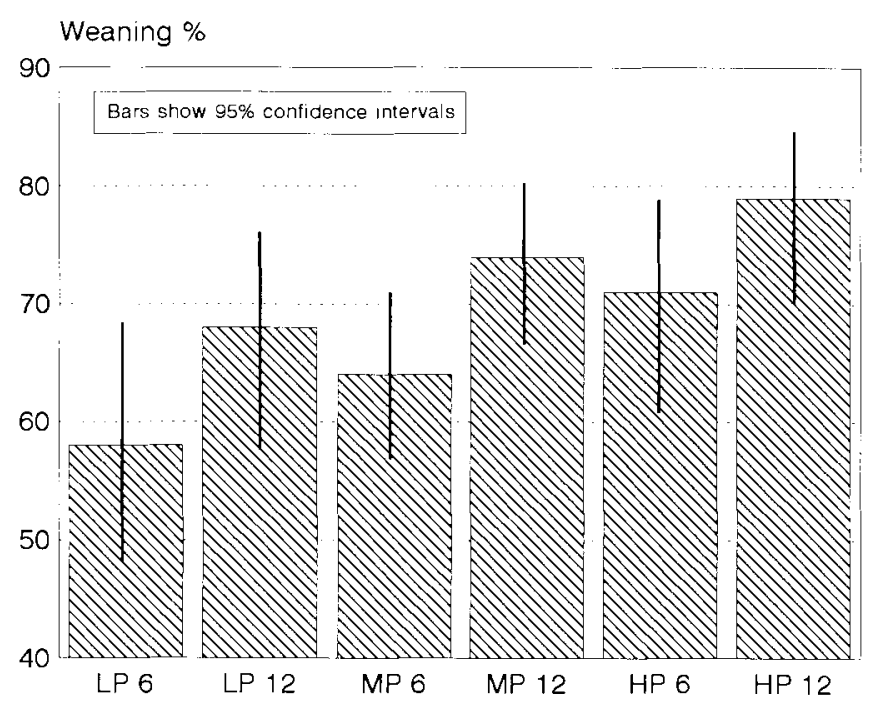

Figure 3 Average weaning percentages of cows in the different treatments, with $95 \%$ confidence intervals.

Period effect and a linear Levels effect are just not significant ( $P=0.0563$ and $P=0.0560$ respectively), but that the joint significance of the model including both these effects (based on a deviance of $3.644+3.651$ with $2 d f$ ) was $P=0.0261$. Taking this as justification for the model, the confidence intervals shown in Figure 3 were calculated.

Thus, the analysis suggests that both the period of supplementation and the level of supplementation have an influence on the number of calves weaned. This suggests that the $P$ reserves may only be depleted to a certain limit, after which reproduction is impaired. Over four calving seasons, the reproductive performance of cows receiving even the lowest level of supplementary P (LP 6), was slightly better than that of cows receiving no $P$ supplement $(-P)$ at Armoedsvlakte, i.e. calving percentages of $100,22,89$ and $56 \%$ in the present trial (Annexure A) and 83, 29, 55 and 26\%, respectively, in the trial by Read et al. (1986a). The reproductive performance improved with increasing levels of supplementary P, e.g. the HP 6 group had calving percentages of 91, 82, 91 and $73 \%$, respectively for their first four successive seasons.

Although none of the calf mortalities between birth and weaning could be linked directly to any effect of treatment per se, especially those in the HP 6 group during 1986/87, there was a tendency for the 12-month groups to have fewer calf mortalities. The actual overall calf crops weaned (Annexure A) in the LP 6 and LP 12 groups were similar over four seasons (64\% and 66\%), thereby suggesting that at this low level of supplementation (LP) and over the period of supplementation used in this study, little advantage was gained from the extra P supplied during the 'dry' months of the cows. It may be argued that in the long-term, i.e. over the cow's reproductive lifespan, the conclusion might be different. However, calculation of the results over five breeding cycles, produced weaning percentages of $71 \%$ (LP 6) and 70\% (LP 12). Within the six-month groups the performance of the MP 6 and HP 6 groups was similar, producing weaning percentages of $72 \%$ and $73 \%$ respectively over four years. However, calculation of the results over five breeding cycles, produced weaning percentages of $77 \%$ (MP 6) and 74\% (HP 6). In the case of the MP 12 and HP 12 groups, the weaning percentages of
$79 \%$ and $85 \%$ over four breeding cycles, changed to $77 \%$ and $86 \%$, when calculated over five breeding cycles. By comparison, in the previous trial at Armoedsvlakte (Read et al., 1986a), the $-\mathrm{P}$ and $+\mathrm{P}$ groups had calving percentages of 51 and $79 \%$, respectively, and weaning percentages of 48 and $73 \%$, respectively, over five breeding cycles. Thus, in terms of weaning percentage, the MP 6, HP 6, MP 12 and HP 12 groups all did the same or better than the $+P$ group in the trial by Read et al. (1986a) and even the LP 6 and LP 12 groups were not lagging far behind.

\section{Body mass of calves}

Means for birth mass, weaning mass and average daily gain (ADG) of the calves in the different treatments over five years of the trial, are given in Table 4 . The ANOVA for average birth mass of the calves only, is given as a footnote in Table 4 . The annual average weaning mass of the calves from the different treatments is also presented in Figure 4.

Because of the possibility of large climatic differences between calving seasons, the factor Year was included as an indicator thereof. The non-significance of the last three interactions $(\mathrm{Y} \times \mathrm{L} ; \mathrm{Y} \times \mathrm{P}$ and $\mathrm{Y} \times \mathrm{L} \times \mathrm{P})$, but the significance of the main effect Year indicates that although there were differences in the seasonal mean birth masses, the differences between treatment means were consistent across years. There was no interaction between Level and Period, nor any main effect owing to Period, but the Level main effect was significant $(P=0.0463)$. Apparently, birth mass varied according to the level of supplementation received by cows. Examining the means for Level, the observed values of $33.8 \pm 0.624$ and

Table 4 Means for birth mass, weaning mass and average daily gain (ADG) of calves in the different treatments over five years of the trial

\begin{tabular}{lccc}
\hline Treatment $^{1}$ & $\begin{array}{c}\text { Birth mass }^{2} \\
\mathrm{~kg} \pm \mathrm{se}\end{array}$ & $\begin{array}{c}\text { Weaning mass } \\
\mathrm{kg} \pm \mathrm{se}\end{array}$ & $\begin{array}{c}\text { ADG } \\
\mathrm{g}^{\mathrm{se} \mathrm{day}}{ }^{-1}\end{array}$ \\
\hline LP 6 & $33.52 \pm 0.94$ & $199.5 \pm 5.29$ & $809 \pm 24$ \\
MP 6 & $35.15 \pm 0.80$ & $214.3 \pm 4.46$ & $873 \pm 20$ \\
HP 6 & $34.95 \pm 0.75$ & $209.5 \pm 4.18$ & $852 \pm 19$ \\
LP 12 & $34.13 \pm 0.82$ & $207.0 \pm 4.57$ & $844 \pm 21$ \\
MP 12 & $35.22 \pm 0.72$ & $209.5 \pm 4.05$ & $850 \pm 18$ \\
HP 12 & $36.21 \pm 0.70$ & $211.3 \pm 3.95$ & $854 \pm 18$ \\
\hline
\end{tabular}

${ }^{1}$ LP 6, MP 6, HP 6: Low, medium and high levels of $P$ for 6 months/year.

LP 12, MP 12, HP [2: Low, medium and high levels of $P$ all year round.

${ }^{2}$ ANOVA (Analysis of variance) table for the birth mass of calves over five years of the trial.

\begin{tabular}{lccc}
\hline Source of variation & $d f^{3}$ & Mean square & Significance level \\
\hline Year $=\mathrm{Y}$ & 4 & 225.0188 & 0.0000 \\
Level $=\mathrm{L}$ & 2 & 65.6290 & 0.0463 \\
Period $=\mathrm{P}$ & 1 & 27.8369 & 0.2512 \\
$\mathrm{~L} \times \mathrm{P}$ & 2 & 9.1105 & 0.6489 \\
$\mathrm{Y} \times \mathrm{L}$ & 8 & 9.2860 & 0.8949 \\
$\mathrm{Y} \times \mathrm{P}$ & 4 & 15.8100 & 0.5577 \\
$\mathrm{Y} \times \mathrm{L} \times \mathrm{P}$ & 8 & 23.8319 & 0.3423 \\
Error & 198 & 21.0235 & \\
\hline
\end{tabular}

${ }^{3} d f=$ Degrees of freedom 


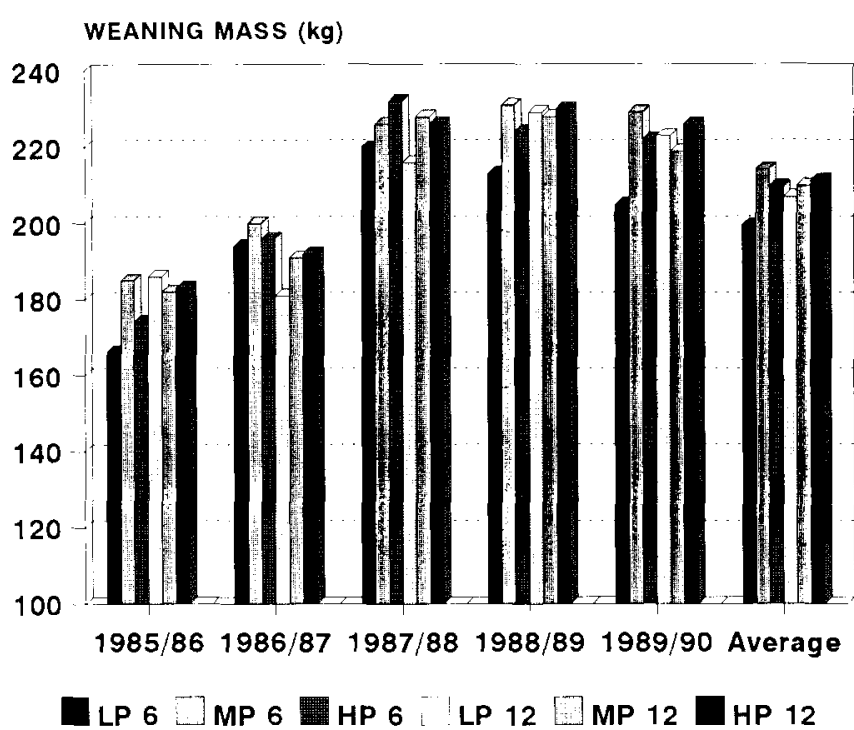

Figure 4 Annual average weaning mass of the calves from the different treatments.

$33.8 \pm 0.624$ for $M$ and $H$ respectively, suggest that the cows receiving the least supplementation were most stressed by the P-deficiency.

The ANOVA tables for weaning mass and average daily gain (ADG), similar to that given for birth mass in Table 4, showed only significant Year main effects. Thus, varying supplementation did not seem to have resulted in varying responses in the case of these variables. Averaged over all available data, the weaning mass was $208.2 \pm 1.70 \mathrm{~kg}$ and the ADG was $0.845 \pm 0.00774 \mathrm{~kg} \mathrm{day}^{-1}$.

As mentioned earlier, there was a strong tendency for weaning mass of calves (Figure 4), as well as for birth mass, to increase with dam age, commensurate with increases in body mass of the cows. However, within individual calving seasons, the average birth and weaning mass of the calves differed little between treatments, suggesting that in times of nutrient deficiencies, the cow sacrificed her own body tissues to shield the calf from such deficiencies, ensuring the existence of the species. Differences in average weaning mass also reflect individual genetic variation in milk yield and growth potential, as well as differences in weaning mass between bulls and heifers, especially since there were some imbalances in the numbers of bulls and heifers weaned in the respective treatments. However, there was a tendency (Figure 4) for the LP 6 and LP 12 groups to wean lighter calves, suggesting that there is a limit to which body reserves of the dam can be utilized before having an effect on milk yield and the calf. Read et al. (1986a) reported a 27.5\% difference (231.8 $\mathrm{kg}$ vs $181.8 \mathrm{~kg}$ ) in the average weaning mass of calves (corrected to 210 days of age) from supplemented and unsupplemented dams at Armoedsvlakte. The weaning mass of the group receiving the least supplementary $P$ in the present trial (LP 6), was $200 \mathrm{~kg}$, calculated over five years, which is considerably better than the $181.8 \mathrm{~kg}$ reported by Read et al . (1986a) for unsupplemented animals.

\section{Intake of salt lick}

The average daily intake of the salt $(\mathrm{NaCl})$ lick by the cows, is presented in Table 5.

It is suspected that results of the present trial, as well as those by Read et al. (1986a), may have been confounded by some interaction between the effects of a $\mathrm{P}$ deficiency and those of $\mathrm{NaCl}$, i.e. detrimental effects of a high $\mathrm{NaCl}$ intake on animal performance (De Waal et al., 1989a,b). Based on knowledge gained from other $\mathrm{P}$ supplementation trials with cattle in the Northern Cape at Koopmansfontein (H.O. de Waal, M.L. Jonker \& C.B. van Zyl, 1993; unpub. data) and Saratoga (H.P. Spangenberg, J.M. van den Heever, H.O. de Waal, E. Graupner \& J.M. Smith, 1995; unpub. data), the widely used procedure of monitoring lick intake monthly on a group basis (across all treatments, inclusive of bulls during the breeding season and calves at foot), proved to be ineffective, because: (i) lick consumption should be monitored at much shorter intervals, preferably every seven days, but not longer than 14 days; (ii) calculation of the average daily lick intake of a group of animals, especially where $\mathrm{NaCl}$ is involved as the sole component of a lick, tends to mask the large variation in intake between animals. It may be useful and important to observe the behaviour of animals at frequent intervals, especially at the lick troughs; (iii) consumption of the lick by the calves would have increased gradually from birth till weaning, again affecting the calculation of the daily intake by the cows. Although it requires additional facilities (e.g. creep feeding type enclosures for calves and elevated troughs for cows), it would be better to determine the lick intake of cows and calves separately, as was the case in a trial at Glen (Read et al., 1986a); and (jv) because P supplementation altered the number of calves born annually, this also would have a variable effect on the calculation of an average lick consumption.

In the absence of details provided for the previous trial at Armoedsvlakte, it was deduced (Table 8; Read et al., 1986a) that the $+\mathrm{P}$ cows consumed on average about $59 \mathrm{~g} \mathrm{NaCl} \mathrm{day}^{-1}$

Table 5 Average daily intake ${ }^{1}$ of the salt $(\mathrm{NaCl})$ lick by the cows across all treatment groups during different months of the trial

\begin{tabular}{|c|c|c|c|c|c|c|c|}
\hline \multirow[b]{3}{*}{ Month } & \multicolumn{7}{|c|}{ Year } \\
\hline & 1984 & 1985 & 1986 & 1987 & 1988 & 1989 & 1990 \\
\hline & \multicolumn{7}{|c|}{ Lick intake ( $\mathrm{g} \mathrm{NaCl}$ day $\left.^{-1}\right)$} \\
\hline January & - & 70 & 101 & 111 & 50 & 77 & 102 \\
\hline February & - & 78 & 140 & 251 & 54 & 57 & 113 \\
\hline March & - & 49 & 185 & 132 & 53 & 106 & 106 \\
\hline April & - & 101 & 231 & 164 & 55 & 111 & 83 \\
\hline May & - & 98 & 253 & 185 & 53 & 134 & 108 \\
\hline June & - & 100 & 219 & 137 & 56 & 75 & - \\
\hline July & - & 123 & 185 & 132 & 106 & 54 & - \\
\hline August & - & 75 & 106 & 106 & 54 & 51 & - \\
\hline September & 76 & 106 & 164 & 164 & 28 & 84 & - \\
\hline October & 132 & 185 & 132 & 106 & 21 & 81 & - \\
\hline November & 66 & 178 & 104 & 137 & 56 & 111 & - \\
\hline December & 96 & 90 & 124 & 181 & 52 & 105 & - \\
\hline
\end{tabular}

${ }^{1}$ Estimated by dividing the amount of salt lick consumed by the total number of adult cattle (cows and bulls). 
(e.g. $47,74,61,62$ and $52 \mathrm{~g} \mathrm{NaCl} \mathrm{day}^{-1}$, respectively, for successive years). The consumption of $\mathrm{NaCl}$ by the $-\mathrm{P}$ group is, however, unknown. In view of the experience gained from the two trials at Koopmansfontein and Saratoga (cited earlier in this section), the cows in the -P group may have consumed much more $\mathrm{NaCl}$ than the $+\mathrm{P}$ cows; as suggested by the estimated higher average daily intake of $\mathrm{NaCl}\left(110 \mathrm{~g} \mathrm{NaCl}\right.$ day $^{-1}$; e.g. $93,104,162,151,53,87$ and $102 \mathrm{~g} \mathrm{NaCl}_{\text {day }}{ }^{-1}$, respectively, for successive years, or parts of years) in the present trial (Table 5). At Koopmansfontein and Saratoga, a highly irregular and high (compulsive) intake of salt licks were noted by certain individuals in the -P group, with detrimental effects on the cows (i.e. huge losses in body mass and even deaths at Koopmansfontein). At Koopmansfontein, the supplemented $(+\mathrm{P})$ cows also had a high lick intake (salt/dicalcium phosphate lick ad lib.), but not as high as the -P group, and also lost body mass, but again not to the same extent as the -P group. As a result, the reproductive performance of the $+\mathrm{P}$ cows dropped sharply during the first two breeding cycles, in spite of an average voluntary daily intake of about $18 \mathrm{~g} \mathrm{P}$ $\mathrm{day}^{-1}$. From the beginning of the second year of that trial, the lick intake of both groups $(-\mathrm{P}$ and $+\mathrm{P})$ were restricted and only during the third year of the trial did the $+\mathrm{P}$ cows regain a normal level of reproduction, while the $-\mathrm{P}$ cows were still lagging behind.

\section{Financial implications}

The financial advantages of different levels and periods of $P$ supplementation to reproducing beef cows at Armoedsvlakte, are summarized in Table 6, in which the results of the present trial were extrapolated to that of a hypothetical herd of 100 cows.

The prices for dicalcium phosphate and animal produce were those applicable during January 1994, although different prices would not affect the relative differences between treatments. In this exercise the highest returns were made with the supplementation levels and periods represented by treatment HP 12.

\section{Conclusions}

The existence of a $\mathrm{P}$ deficiency in cattle grazing on the pasture at Armoedsvlakte, was revealed once again. The three levels of $\mathrm{P}$ supplementation, as well as the duration of supplementation, created a gradient of animal performance and financial returns. The best financial return on investment in $P$ supplementation to reproducing beef cows was gained by supplementing reproducing beef cows in the HP 12 treatment which provided $16 \mathrm{~g} \mathrm{P}$ day $^{-1}$ during late gestation to late lactation (September to February) and $9 \mathrm{~g} \mathrm{P}$ day $^{-1}$ during the remainder of the year.

It may, however, be argued that the method of supplementation used in this trial, i.e. via rumen fistulae and at fairly high doses every two or three days, might have yielded responses differing from that which would have been obtained with conventional lick supplementation. Given the type of supplementation, i.e. dicalcium phosphate, and the relatively long retention time required by nutrients passing through the ruminant alimentary tract, this was not a major concern. Furthermore, the annual changeover of supplemen-
Table 6 Summary of the effects of different levels and periods of phosphorus $(P)$ supplementation on the economics of a hypothetical herd of reproducing beef cows at Armoedsvlakte

\begin{tabular}{|c|c|c|c|c|c|c|}
\hline \multirow[b]{2}{*}{ Measurement } & \multicolumn{6}{|c|}{ Treatment $^{1}$} \\
\hline & LP 6 & MP 6 & HP 6 & LP 12 & MP 12 & HP 12 \\
\hline $\begin{array}{l}\text { Calves weaned per } 100 \\
\text { cows }\end{array}$ & 58 & 64 & 71 & 68 & 74 & 79 \\
\hline $\begin{array}{l}\text { Average weaning mass } \\
\text { (corrected for } 205 \text { days } \\
\text { of age) }\end{array}$ & 208.2 & 208.2 & 208.2 & 208.2 & 208.2 & 208.2 \\
\hline
\end{tabular}

Income from weaners

(@) R 2.00 per kg live

mass) $\quad$ (R) $\quad 24151 \quad 26650 \quad 29564 \quad 28315 \quad 30814 \quad 32896$

Difference in weaner

income $(\mathrm{R})$

(R)

Cost of $\mathrm{P}$ supplementation (@) R 1.19 per kg

$\begin{array}{lllllllll}\mathrm{DiCaP}) & (\mathrm{R}) & 673 & 1346 & 2154 & 1084 & 2167 & 3386\end{array}$

Difference in weaner

income above supple-

ment cost (R)

Average cow body

$\begin{array}{lllllll}\text { mass } & (\mathrm{kg}) & 472 & 472 & 472 & 505 & 505\end{array}$

Difference in average cow body mass $(\mathrm{kg})$

Difference in income

from culled cows ( 9

$\mathrm{R} 1.80$ per $\mathrm{kg}$ live mass)

(@) 15\% annual replace-

ment) (R)

(R)

$\begin{array}{llllll}472 & 472 & 472 & 505 & 505 & 505\end{array}$

Difference in income

from weaners plus

culled cows above cost

of supplementation (R) $\quad$ - $\quad 1826 \quad 3932 \quad 4644 \quad 6060 \quad 6923$

${ }^{1}$ LP 6, MP 6, HP 6: Low, medium and high levels of P for 6 months/year.

LP 12, MP 12, HP 12: Low, medium and high levels of $P$ all year round.

tation for all cows in September and March (Table 1) and the 100 or 75 day mating seasons, meant that individual cows received their supplements at different time frames relative to their breeding cycle. Since this was the case for cows in all treatments, the overriding concern was to keep the supplementation procedure to the free grazing herd of about 60 breeding cows as simple and practical as possible, with a minimum disturbance because of frequent herding.

\section{Acknowledgements}

The authors acknowledge the contribution of all those involved in this research programme, both in the past and present, especially Dr Elias Engels, Dr Marion Read, Dr Johan Grobbelaar, Hannes Vermeulen, Mrs Heila Terblanché and the late Alfonso Malan and Dr Daan Els.

\section{References}

ACOCKS, J.P.H., 1988. Veld types of South Africa. 3rd Ed. Mem. bot. Surv. S. Afr. No. 57. Government Printer Pretoria.

ARC (AGRICULTURAL RESEARCH COUNCIL), 1980. The nutrient requirements of ruminant livestock. Commonwealth 
Agricultural Bureaux, Farnham Royal, U.K.

DE WAAL, H.O., 1990. Animal production from native pasture (veld) in the Free State Region - a perspective of the grazing ruminant. S. Afr. J. Anim. Sci. 20, 1.

DE WAAL, H.O., BAARD, MARGARIETHA A. \& ENGELS, E.A.N., 1989a. Effects of sodium chloride on sheep. 1. Diet composition, body mass changes and wool production of young Merino wethers grazing native pasture. S. Afr. J. Anim. Sci. 19, 27. DE WAAL, H.O., BAARD, MARGARIETHA A. \& ENGELS, E.A.N., 1989b. Effects of sodium chloride on sheep. 2. Voluntary feed intake and changes in certain rumen parameters of young Merino wethers grazing native pasture. S. Afr. J. Anim. Sci. 19, 34.

DE WAAL, H.O. \& KOEKEMOER, G.J., 1996. Blood, rib bone and rumen fluid as indicators of $P$ status of grazing beef cows supplemented with different levels of phosphorus at Armoedsvlakte. S. Afr. J. Anim. Sci. (in press).

LITTLE, D.A., 1980. Observations on the phosphorus requirement of cattle for growth. Res. Vet. Sci. 28, 258.

LITTLE, D.A., McLEAN, R.W. \& WINTER, W.H., 1977. Prediction of the phosphorus content of herbage consumed by grazing cattle. J. agric. Sci., Camb. 88, 533.

MEISSNER, H.H., HOFMEYR, H.S., VAN RENSBURG, W.J.J. \& PIENAAR, J.P., 1983. Classification of livestock for realistic prediction of substitution values in terms of a biologically defined Large Stock Unit. Tech. Comm. No. 175. Department of Agriculture, Pretoria.

READ, MARION V.P., 1984. Animal performance from natural pastures and the effects of phosphorus supplementation. M.Sc. (Agric.) thesis. University of Stellenbosch.

READ, MARION V.P., ENGELS, E.A.N. \& SMITH W.A., 1986a. Phosphorus and the grazing ruminant. 2. The effects of supplementary $\mathrm{P}$ on cattle at Glen and Armoedsvlakte. $S$. Afr. $J$. Anim. Sci. 16, 7.

READ, MARION V.P., ENGELS, E.A.N. \& SMITH W.A., 1986 b. Phosphorus and the grazing ruminant. 3. The rib bone sample as an indicator of the P status of cattle. S. Afr. J. Anim. Sci. 16, 13.

READ, MARION V.P., ENGELS, E.A.N. \& SMITH W.A., $1986 \mathrm{c}$. Phosphorus and the grazing ruminant. 4. Blood and faecal grab samples as indicators of the P status of cattle. S. Afr. J. Anim. Sci. $16,18$.

SAS INSTITUTE INC., 1989. SAS/IML ${ }^{\mathrm{R}}$ Software: Usage and reference, Version 6 (1st edn.). : SAS Institute Inc., 1989. Cary, NC.

THEILER, A., 1912. Facts and theories about styfziekte and lamziekte. Second Report Dir. Vet. Res. pp 7-78.
Annexure A The reproductive performance of cows that received different levels of supplementary phosphorus $(P)$ for six or 12 months per year (1985/86 to 1989/90)

\begin{tabular}{|c|c|c|c|c|c|c|}
\hline \multirow[b]{3}{*}{ Treatment $^{1}$} & \multicolumn{6}{|c|}{ Calving season } \\
\hline & $1985 / 86$ & 1986/87 & $1987 / 88$ & 1988/89 & $1989 / 90$ & $1985-1989$ \\
\hline & \multicolumn{6}{|c|}{ Calves born per cow; and Calving percentage (\%) } \\
\hline \multirow[t]{2}{*}{ LP 6} & $9 / 9$ & $2 / 9$ & $8 / 9$ & $5 / 9$ & $9 / 9$ & $33 / 45$ \\
\hline & 100 & 22 & 89 & 56 & 100 & 73.3 \\
\hline \multirow[t]{2}{*}{ MP 6} & $9 / 9$ & $5 / 9$ & $7 / 9$ & $8 / 9$ & $8 / 8$ & $37 / 44$ \\
\hline & 100 & 57 & 78 & 89 & 100 & 84.1 \\
\hline \multirow[t]{2}{*}{ HP 6} & $10 / 11$ & $9 / 11$ & $10 / 11$ & $8 / 11$ & $9 / 10$ & $46 / 54$ \\
\hline & 91 & 82 & 91 & 73 & 90 & 85.2 \\
\hline \multirow[t]{2}{*}{ LP 12} & $10 / 11$ & $10 / 11$ & $3 / 11$ & $9 / 11$ & $10 / 10$ & $42 / 54$ \\
\hline & 91 & 91 & 27 & 82 & 100 & 77.8 \\
\hline \multirow[t]{2}{*}{ MP 12} & $11 / 11$ & $9 / 11$ & $8 / 11$ & $9 / 10$ & $7 / 10$ & $44 / 53$ \\
\hline & 100 & 82 & 73 & 90 & 70 & 83.0 \\
\hline \multirow[t]{3}{*}{ HP 12} & $10 / 10$ & $8 / 10$ & $7 / 10$ & $9 / 10$ & $9 / 10$ & $43 / 50$ \\
\hline & 100 & 80 & 70 & 90 & 90 & 86.0 \\
\hline & \multicolumn{6}{|c|}{ Calves weaned per cow; and Weaning percentage (\%) } \\
\hline \multirow[t]{2}{*}{ LP 6} & $8 / 9$ & $2 / 9$ & $8 / 9$ & $5 / 9$ & $9 / 9$ & $32 / 45$ \\
\hline & 89 & 22 & 89 & 56 & 100 & 71.1 \\
\hline \multirow[t]{2}{*}{ MP 6} & $7 / 9$ & $5 / 9$ & $7 / 9$ & $7 / 9$ & $8 / 8$ & $34 / 44$ \\
\hline & 78 & 56 & 78 & 78 & 100 & 77.3 \\
\hline \multirow[t]{2}{*}{ HP 6} & $9 / 11$ & $5 / 11$ & $10 / 11$ & $8 / 11$ & $8 / 10$ & $40 / 54$ \\
\hline & 82 & 46 & 91 & 73 & 80 & 74.1 \\
\hline \multirow[t]{2}{*}{ LP 12} & $9 / 11$ & $9 / 11$ & $3 / 11$ & $8 / 11$ & $9 / 10$ & $38 / 54$ \\
\hline & 82 & 82 & 27 & 73 & 90 & 70.4 \\
\hline \multirow[t]{2}{*}{ MP 12} & $10 / 11$ & $9 / 11$ & $7 / 11$ & $8 / 10$ & $7 / 10$ & $41 / 53$ \\
\hline & 91 & 82 & 64 & 80 & 70 & 77.4 \\
\hline \multirow[t]{2}{*}{ HP 12} & $10 / 10$ & $8 / 10$ & $7 / 10$ & $9 / 10$ & $9 / 10$ & $43 / 50$ \\
\hline & 100 & 80 & 70 & 90 & 90 & 86.0 \\
\hline
\end{tabular}

${ }^{1}$ LP 6, MP 6, HP 6: Low, medium and high levels of P for 6 months/year. LP 12, MP 12, HP 12: Low, medium and high levels of $P$ all year round. 